\title{
Effect of Time Management on the Job Satisfaction and Motivation of Teacher Educators: A Narrative Analysis
}

\author{
Zafarullah Sahito $^{1,2} \&$ Pertti Vaisanen ${ }^{1}$ \\ ${ }^{1}$ School of Applied Educational Sciences and Teacher Education, Philosophical Faculty, University of Eastern Finland, \\ Finland \\ ${ }^{2}$ Sukkur IBA, Sindh, Pakistan, Airport Road, Sukkur, Sindh, Pakistan \\ Correspondence: Zafarullah Sahito, School of Applied Educational Sciences and Teacher Education, Philosophical \\ Faculty, University of Eastern Finland and Sukkur IBA, Sindh, Pakistan, Airport Road, Sukkur, Sindh, Pakistan
}

Received: March 12, 2017

Accepted: April 12, 2017

Online Published: April 18, 2017

doi:10.5430/ijhe.v6n2p213

URL: https://doi.org/10.5430/ijhe.v6n2p213

\begin{abstract}
The present study was conducted to investigate the relationship between time management, job satisfaction and motivation among teacher educators in university departments, institutes and faculties of education in the Sindh province of Pakistan. Using an interview approach, the researchers recorded the professional stories of 40 teacher educators. The interviews and the analysis focused particularly on teacher educators' skills, routines and characteristics related to time management, job satisfaction and motivation. This article advances current knowledge by revealing the values of narrative analysis including, especially, qualitative research methods as a means for disseminating the evidence-based information. In so doing, it offers teacher educators and heads of universities, faculties, institutes and departments a reliable resource for understanding how teacher educators improve their time management skills to increase job satisfaction and motivation and make their professional and personal lives more meaningful.
\end{abstract}

Keywords: Time management, Job satisfaction and motivation, Narrative analysis, Teacher educators, Professional and personal life

\section{Introduction}

Time management (TM) is the process of determining needs, setting of goals, prioritising and planning the tasks to achieve the organisational goals (Lakein, 1973), where a significant relation has been found between job stress and TM variables and employees' goal setting, planning and performance evaluation (Khodaveisi, Bahar \& Ahmadi, 2015). The process to using time effectively to achieve maximum productivity involves managing work schedules and engaging in advance planning, organizing and implementation to achieve the organisational objectives (Sahito, Khawaja, Panhwar, Siddiqui, \& Saeed, 2016), which are necessary for sustainability of the employees and organisation. There is no permanent definition of TM; however, it is clear that monitoring and controlling time are critical for helping people complete their assignments (Eilam \& Aharon, 2003). As David (1999) noted, to make good use of time, time must be managed through a variety of relevant practices (Allen, 2001) to settle down the necessary matters. As time management skills (TMSs) improve, teachers have been shown to experience less job stress, which can significantly influence their quality of life (Khodaveisi, Bahar \& Ahmadi, 2015). Today, since money and knowledge are no longer sufficient to ensure high performance, the primary factor in job success is the proper use of time, or TM (Moghimi, 2006). TM involves effectively controlling and planning time in order to reduce stress, which is one of the most important factor in professional success (Mancini, 2003). Thus, to improve job satisfaction and motivation, TM uses goal setting, prioritising, planning and performance evaluation (Mohammadi, 2010; Javaheri, 2005) in order to make employees happy and healthy.

Modern lives are increasingly hurried. To save and manage time, people want to do their work faster, eat faster, use fastest modes of transport, work till late night, sleep for less time and make phone calls while driving, eating food and working in office (Garhammer, 2002). These practices illustrate current perceptions of time and the importance to managing time well in organizational contexts (Palmer \& Schoorman, 1999) to achieve organisational goals in order to reduce employees' time pressures (Jackson \& Martin, 1996; Major et al., 2002; Teuchmann et al., 1999). However, the time pressures can only be minimised through proper TM, as indicated by many theoretical models and research designs (Ancona et al., 2001; George \& Jones, 2000; Wright, 2002) seeking to manage time and create a supportive working environment (Macan, 1994). In educational institutions, TM refers to the processes of the constructing and 
implementing time table, distributing subjects and workloads, planning lessons, ensuring regularity and punctuality, planning in advance, offering counseling and guidance, allocating and using time effectively and organizing and preparing co-curricular activities (Sahito et. al, 2016) to make system practical and beneficial for all stakeholders.

\subsection{Time and its Importance}

Time refers to indefinite and continued progress of existence and events that occur in apparently irreversible succession from the past through the present and, finally, leads towards the future (The American Heritage Dictionary of the English Language, 2011; The Concise Oxford Dictionary, 2011; Webster's New World College Dictionary, 2010). Time is critical for providing human beings opportunities to think about their status, conditions and environment and to make, change, create and maintain various systems. Time can be strong, transparent and practical, comprising rules that govern our daily lives and help members of society achieve success. Since proper implementing rules and regulations is critical for both individuals and nations, time is considered a great cure for all types of problems. With time, people can overcome all hurdles, issues and difficulties, sometimes even turning sorrows into happiness (and vice versa). Good intentions, time management, passion and hard work are all fundamental for achieving positive results. All stakeholders must make decisions allocating time to every activity. These decisions can determine a leader's popularity and effectiveness (Grissom, Loeb \& Master, 2013; Horng, Klasik \& Loeb, 2010), which leads the institution and employees towards quality education. Human history shows that people who adopt the above fundamental rules and successfully manage their time are more successful.

Time and TM are particularly important in the field of education. TMSs are especially critical for teachers, since, like all professionals, teachers need to perform well to improve their performance. Teachers work as architects, building children's future and, thus, the future of the world. Similarly, principals must invest their time in different curricular activities, such as developing and transmitting instructions and coaching and supporting teachers' professional development, all of which are directly associated with positive student outcomes (Grissom, Loeb, \& Master, 2013; May, Huff, \& Goldring, 2012), teacher satisfaction, motivation and quality education.

Time is an important component of quantity to measure the various events and their timing to compare the duration or the intervals to quantify the rates of change of quantities in reality and in the conscious experience (Internet Encyclopedia of Philosophy, 2010; The New Oxford Dictionary of English, 2001). Time remained an important subject of study in most of the fields of study such as religion, philosophy, science, business, industry, sports and the performing arts, that they all incorporated some notion of time into their respective measuring systems (Carroll, 2009; Frank, 2011) as per their nature, need and requirement. There are two main viewpoints explained by the prominent philosophers such as the time is part of the fundamental structure of the universe and an independent dimension in which events occur in sequence. While in the second view, the time is neither an event nor a thing, which is not measurable nor can be travelled (Douglas, 2006; Matt, 2006; Mattey, \& Davis, 1997), but it is counting and measuring the completion of task done by some instruments.

\subsection{Statement of the Problem}

This study was designed to explore and investigate the TM habits, routines and skills of teacher educators (TEs) who use time schedules to complete their professional assignments. This study also explores TEs' activities related to planning, designing, managing, implementing, evaluating and achieving their teaching learning objectives and organisational goals. To examine these TM activities, the researchers observed, collected and analysed TEs' processes and procedures to develop accurate and authentic results based on evidences about the relationship of TEs' TM and job satisfaction and motivation (JSM). The study also explored the effectiveness of teacher education departments or institutions in training teachers to perform their roles successfully. The study objective was to provide insights that could support radical reforms related to achieving and maintaining quality education in teacher education departments or institutions and school system.

\section{Time Management and its Scope}

TM is a process to managing time according to the requirements of different assignments and activities with the goal of ensuring organisational success and maximizing benefits by utilising, saving and not wasting time or energy (Sahito et. al, 2016). Effective TM involves using time in an optimal way to increase productivity and success. It requires managing work schedules to achieve organisational goals through advanced planning, organisation and implementation. TM is critical asset for both professionals and organisations, since it concerns the discovery and application of efficient methods to complete assignments within a specified period (Sahito et. al, 2016) and at the necessary quality level. It is a human nature to allocate time according to interest and comfort; thus, within a work 
organisation, employees tend to spend their time on easy tasks. However, proper TM is the only way to develop good skills and habits to achieve professional success.

TM refers to the techniques used to manage (Davis, 2000; Jex \& Elacqua, 1999; Macan, 1996, 1994; Macan et al., 1990; Mudrack, 1997) and use time effectively to accomplish various tasks (Orpen, 1994; Slaven \& Totterdell, 1993; Woolfolk \& Woolfolk, 1986) through suitable planning and allocation of time (Burt \& Kemp, 1994; Francis-Smythe \& Robertson, 1999a). It allows people to follow structured and purposive paths (Bond \& Feather, 1988; Sabelis, 2001; Strongman \& Burt, 2000; Vodanovich \& Seib, 1997) to gain sufficient insight to distribute time efficiently across multiple activities (King et al., 1986), which helps individuals to maximise and enhance their intellectual productivity (Britton \& Tesser, 1991). One study of principals and their time allocation practices found that principals allocate their time across a variety of responsibilities, including matters related to employees, budgeting, student services, external relations and a host of other areas (Goldring et al., 2008; Grissom, Loeb \& Master 2013; Horng, Klasik \& Loeb, 2010; Spillane, Camburn \& Pareja, 2007; Spillane \& Hunt, 2010). Principals also spend time on organisational management, including, specifically, personnel management, budgeting and other school outcomes (Horng, Klasik, \& Loeb, 2010; May, Huff, \& Goldring, 2012). At the teacher level, research has shown that TM trainings can help teachers increase their TMSs (Claessens, Eerde, Rutte, \& Roe, 2007) for better results.

\subsection{Time Management Skills and Techniques}

TMSs are associated with the allocation of time across the job tasks and higher measures of job performance. Time allocation is critical for managing instruction and improving performance. Thus, TM is a worthwhile strategy for supporting stakeholders in focusing on instruction and pursuing the necessary activities related the improvement. TM techniques and behaviors (TMTB) tend to share some common. TM techniques and behaviours tend to share several common traits and can be classified into several groups, including short-range planning, long-range planning and time attitudes (Britton \& Tesser, 1991). TM involves setting goals and priorities, making lists and scheduling, and organising (Macan, 1994) the preplanned activities related to positive behaviours, which support effective time use during the completion of goal-directed activities (Claessens et al., 2007, 262). Principals, in particular, must engage in multidimensional TM involving skills and behaviors related to short-range planning, time consciousness, delegation, and focus. Such activities are easier to implement and manage in smaller schools; however, in all types of institutions, better TMSs are associated with the more productive time investments and, thus, more profitable production (Horng, Klasik, \& Loeb, 2010; Robinson, Lloyd, \& Rowe, 2008) known as quality education.

\section{Time Management, Job Satisfaction and Motivation}

TM is the use of self-regulation processes (Griffiths, 2003) to manage risky behaviours (King et al., 1986) through plans, strategies and their efficient utilisation (Eilam \& Aharon, 2003). TM procedures can help the individuals achieve their goals (Hall \& Hursch, 1982) by identifying the activities necessary to complete their plans (Kaufman-Scarborough \& Lindquist, 1999), improve productivity, alleviate stress (Lay \& Schouwenburg, 1993), increase satisfaction and enhance motivation. TM behaviours have been found to be positively correlated with perceived control, job satisfaction and health and negatively associated with stress (Claessens et. al, 2007). This suggest that TM can reduce stress and increase satisfaction, motivation and effort among employees (Alvani, 2008). Furthermore, significant relations have been found between job stress and such TM variables and dimensions as goal setting, planning, and performance evaluation (Khodaveisi, Bahar \& Ahmadi, 2015), which can increase teachers' work satisfaction, motivation and quality of life. Improving TMSs has been shown to reduce job stress among physical education teachers, which significantly influencing their quality of life (Khodaveisi, Bahar \& Ahmadi, 2015). TMSs also enable professionals to work in demanding workplaces by helping them to use their limited time in a useful and effective manner and by motivating them to focus their attention on high-priority matters to improve their overall job performance (Claessens et al., 2007) and quality education through having JSM.

\subsection{Time Management and Performance}

Effective TM reduces job stress, which can be an important barrier to job performance (Jamal, 1984) because of the need to accomplish the goals within a set time schedule (Schuler, 1979) and pre planning. Individuals who have greater control over their time experience less tension and exhibit fewer physical symptoms of stress (Macan, 1994). Since stress has been negatively correlated with self-assessed job performance, reducing stress through TM can minimise work strain and increase job performance (Claessens et al., 2004) in an effective organisation. A positive association has also been found between TM and employee health, mediated by perceived control and conflicts among the various demands of work and family support (Adams \& Jex, 1999) and responsibilities. TM helps professionals to improve their job efficiency by allocating time appropriately to each of their various job tasks (Hall \& Hursch, 1982; Orpen, 1994; Schuler, 1979). This, in turn, helps improve workers' outcomes and enable them to 
work smarter in the private sector (Green \& Skinner, 2005) for maximising the product. TMS-related job demands and expectations are increasing daily and affect whether a job is feasible or not (Institute for Educational Leadership, 2000, p. 12). Furthermore, research has shown that job performance depends on several functions and factors that are difficult to observe or measure, since organisational outcomes are affected by both individuals' performance and organisational policies, procedures and implementation (Hallinger \& Heck, 1998) may be positive and vice versa.

TM affects various factors that might influence job performance. Professionals who manage their time report less emotional exhaustion, which is the most important factor in professional burnout (Peeters \& Rutte, 2005). Those who undergo TM training also report greater job satisfaction (Macan et al., 1990), motivation and work/home balance (Green \& Skinner, 2005). Satisfaction and satisfaction-related factors have been shown to fundamentally contribute to employees' performance (Judge et al., 2001), even though every organisation faces limited resources, time and skills (Ajzen, 1991). TM can increase perceptions of control by relaxing employees' attitudes (Macan, 1994), if employees do not engage themselves in new behaviors, they cannot know which behaviors are most productive. In such situations, TM can enhance the performance and support objectives (Ajzen, 1991). TM also predicts job performance; for example, sales men with better TMSs have higher sales (Barling et al., 1996), college students with better TMSs report higher grades (Britton \& Tesser, 1991; Macan et al., 1990) and county extension directors with better TMSs are rated higher by their superiors (Radhakrishna, Yoder, \& Baggett, 1991). These results show that job performance, TM and job satisfaction are inextricably linked.

\section{Methodology}

\subsection{Research Method and Procedure}

This study followed a qualitative research design rooted in the philosophical assumptions of epistemology and ontology (Crotty, 1998) and supported by the interpretivism. Interpretivism suggests that there exist multiple realities, and epistemological constructionism suggests that knowledge is both constructed and subjective in nature (Creswell, 2009) in order to understand the phenomenon. This study conducted semi-structured interviews to collect data from a sample of the TEs recruited from different departments using snowball sampling (or "friends of friends") approach. All were asked to share their real professional life experiences regarding TM and JSM. All were also provided with a short written description of the topic of the study. Then, the TEs were invite to share their experiences with learning, professional development, success and JSM, with special reference to TM in their profession.

The interview data were kept confidential, and the interviewees' identities were protected (Shaw \& Gould, 2001). The qualitative research approach was used to explore and define the participants' personal meanings based on their narrated sentences, without losing any richness or genuineness of the original spoken text (Flick, 1998; Strauss \& Corbin, 1998). To ensure the validity of the tools and the data, the study was guided and supported by the relativist approach and the characterizing traits list (Sparkes \& Smith, 2009, 2014). The list outlines several research considerations, such as the topic worthiness and the richness; the significance of the contribution to the literature; thoroughness and objectivity; proper and appropriate sample selection; the meaningful, significant and clarity of claims generated from the data; the rationality and soundness of research; and the appropriate selection of methods based on the needs and requirements of the study topic and results (Tracy, 2010).

The data were analysed using narrative inquiry approach, since narrative inquiry has long been considered a suitable analysis tool in the fields of cognitive science, organisational studies, knowledge theory, sociology and education studies. Narrative inquiry captures the personal and human dimensions of experience over time and explore the relationship between individual experience and cultural context (Clandinin \& Connelly 2000). There are several different forms of narrative analysis. Some approaches focus on story content, others focus on the meaning, and still others focus on both, depending on the philosophical position. These stories can be considered a window into knowable reality and can be viewed as socially situated knowledge constructions that value messiness, differences, depth and texture of experienced life (Polkinghorne, 1995). This analysis process is often called narrative analysis, or the exploration of narratives meanings discovered through research process (Riessman, 2008). Narrative analysis treats stories as a creator of knowledge that constitutes the narrator's own social reality (Etherington, 2004) in black and white mode clearly. Narrative analysis can be conducted with a researcher's own clients (Etherington, 2006, 2000; Wosket, 1999), with other peoples' clients (Etherington, 2007) or with people who are not clients.

\subsection{Participants}

A total 40 participants were recruited for this study using a snowball method. The snowball approach was chosen to facilitate the collection of in-depth, true and real data. In snowball sampling, the number of participants can vary from 1 or 2 to 30 or 40, depending on the need to report details about each individual or site (Creswell, 2012). To recruit the 
sample, the researchers approached their friends in different education departments to ask them to serve as study participants. After these individuals were interviewed, they were asked to suggest additional friends at other universities. In this way, the researchers were able to recruit a sufficient sample of TEs from different departments in different universities in Sindh, Pakistan. The recruited sample of 40 TEs comprised 19 males and 21 females, including 18 PhDs ( 8 males; 10 females), 10 MPhils (5 males; 5 females) and 12 MEds (6 males; 6 females). With respect to profession, the sample comprised 6 professors ( 1 male; 5 females), 1 associate professor (male), 19 assistant professors ( 8 males; 11 females) and 14 lecturers ( 9 males; 5 females). The participants ranged from 28 to 58 years old, with an average age of 44.65 . Furthermore, $89 \%$ were married, $11 \%$ were single, $53 \%$ lived in an urban environment and $48 \%$ lived in a rural environment.

Of these 40 TEs, 13 TEs were purposefully chosen for an extended and representative analysis. These 13 TEs, who comprised the final purposive sample, were chosen because they explained their stories well and produced interesting, relevant and high-quality data. This representative sample comprised nine males and four females, including two professors (one male; one female), six assistant professors (five male; one female) and five lecturers (three male; two female).

\section{Results}

The final purposive sample of TEs was given numbers in the place of their names, since the researchers assured the participants that their original identities would be kept secret. All interviewed TEs were assigned numbers before the interviews began, which is why the TE numbers range from 1 to 40 . The following presents the most important quotations and narratives recorded and selected for analysis. First with respect to the TEs stories regarding TM in their department, TE 4 commented as follows:

Pre-planning is done for everything in advance in order to manage the time ahead. For example, we review and update outlines of allotted subjects and develop relevant material in a booklet to support lecture planning. (TE 4)

Similar experiences were reported by nine other TEs, most of whom belonged to newly established universities and institutions in the province of Sindh, Pakistan. Pre-planning involves making or is a developing plans in advance to arrange human and material resources (e.g. man, machines and money) to support the implementation of future plans as formal programmes with specified benefits. TE 32 added to the first comment as follows:

The updated outline converts and breaks down into weekly schedules and classes to manage time and classes to complete the course. This outline is shared in with students in the very first class so they can plan for their assignments and coming events. (TE 32)

In the other interviews, 12 more TEs, including six assistant professors and five lecturers, expressed similar experiences. Outline reviews support the addition of new tools and content areas, including new course topics, activities, methods, techniques, innovations and invention for use in the field. New outlines may also include new reference books and research articles for further readings. Ultimately, outlines represent the background planning responsible for developing and supporting the purpose, aims and objectives of a course, programme, degree or national cause. TE 37 added the following:

In outline, counselling and guidance hours for students are mentioned in advance to [allow them] manage time and activities throughout the semester to help their students and themselves. (TE 37)

This comment, which was supported by 20 more TEs who offered counselling hours for individual and group guidance, reveals that counselling and guidance are considered the backbone of the education system and are necessary for teachers and students to get proper direction and be successful. TEs who offer counselling allot specific hours to listen their students' problems and give them guidance in minimising stress and focusing on their studies. TE 3 identified another method of supporting time management, as follows:

The notes, related materials, Power Point presentations, further readings and the list of assignments are designed in advance to manage time throughout the semester. (TE 3)

This comment was supported by 18 more TEs, who stated that they create notes, related materials and Power Point presentations in advance. These TEs also share these materials with their students in advance to encourage them to 
read and become motivated about upcoming topics. Similarly, TE 1 argued that developing guidelines for marks and related activities in advance is very important:

The marks distribution and other related activities, like the first term examination and the second term and final term examinations are designed in advance [and presented on a] one-page document attached with the outline. (TE 1)

In addition to TE 1, 21 other TEs also detailed their marks distribution practices on a piece of paper that they shared and discussed with their students on the first day of class. These teachers also gave students advice on how to use the marks distribution document effectively to prepare for learning, assessments, assignments, presentations, classroom activities, out-of-class activities and out-of-school activities. TE 27 followed up on this comment by relaying a strategy for making the examination and assessment process easier, more understandable and more manageable.

The time slots for examinations, the assessment style, the checking of copies and the announcement of results in classroom are given in advance on the academic calendar to manage time [and help students] to complete all activities on time. (TE 27)

TE 27's comment was supported by 33 other TEs who used examination plans to outline the time, place, content and mode (e.g. subjective, objective or combined) of various assessments. Some TEs also shared previous questions and activities with students to give them an overview of what kind of assessment style to expect. In addition, TE 15 noted the importance of using reminders to support TM.

The soft reminders sent by the head of department and the head of organisation help the TEs focus on completing all of their assignments by or before the deadline. (TE 15)

An additional 27 TEs noted that they managed their activities using reminders. These respondents said that reminders help them work actively on important activities as they approach important deadlines. The TEs used reminders to remember to develop their question papers, check their examination copies, disseminate announcements and share and submit their students' results. They considered these reminders to be "time management bells" that helped them remember to finish their work on or before the deadline. TE 2 added to the discussion on deadlines by noting the importance of managing time and activities during the period between assessing works and sharing the results with students.

After assessing the first- and second-term examinations, the results are announced and copies [of the test] are given to students. [This allows them] to check their progress and the assessment style of the teacher, to receive proper and authentic assessment techniques and to plan for their future progress. (TE 2)

This comment was supported by 16 more TEs, who noted the importance of managing assessments and the announcement of results. Students are given copies of completed exams so that they can check their marks, familiarise themselves with the teacher's assessment style, review the teacher's instructions and re-examine the language of the test questions. It is important for students to focus on activities where they have lost marks, since these areas should be considered for future examinations. Like TE 2, TE 29 also discussed the process of managing time and activities between assessing tests and sharing the results with students:

If any student has any objection and wants to discuss anything regarding the assessed paper and the marks received, he or she may come to discuss with the teacher during counselling hours, and the teacher is responsible for satisfying his or her student(s). (TE 29)

TE 29's comment was supported by 15 more TEs who focused on managing the processes of assessing exams and announcing the results to students. These TEs noted the importance of allowing students to raise objections, discuss reviewed assessments and achieve satisfaction with their marks. This process of viewing, discussing and finalising students' marks helps both students and teachers achieve mutual agreement regarding students' performance. TE 38 contributed to the discussion of marks by highlighting the importance of managing time and activities between assessing tests and sharing the results with students.

The list of students and their marks is published and displayed on a notice board to save and manage time and to maintain transparency in assessment, evaluation and student results. (TE 38) 
An additional 17 TEs stated that they publish and display students' results following the discussion and removal of all objections. These teachers did not want to provoke their students, particularly with respect to assessment and the awarding of marks and grades. They argued that displaying results in this manner is the best way to manage time and address all types of inequalities and injustices. TE 40 identified another important use of TM: to achieve continuous and high-quality work.

For proper time management, all of us (TEs) have to work hard, continuously in our offices and at home to remain satisfied and motivated with our jobs. (TE 40)

This comment was supported by 28 more TEs who said that they work hard and think that this kind of continuous work is the main solution to problems of TM. Furthermore, those TEs who incorporated TMS in their daily lives seemed more satisfied with their jobs and more motivated to work. TE 35 also emphasised the importance of TM in supporting continuous work.

For time management, job satisfaction and motivation, TEs have to design their work schedule in advance and do work continuously to meet and achieve the assignments and activities. (TE 35)

An additional 34 TEs also made their work schedules in advance to ensure that they could implement their work properly and effectively. The results also showed that those TEs who implemented their schedules were more satisfied with their ability to support students, colleagues and other stakeholders. TE 7 contributed to this topic by discussing the relationship between schedule-making and non-schedule-making TEs.

The TEs who make their work schedules in advance and do work continuously become successful due to having a good grip on teaching, training and research work, compared to other TEs. (TE 7)

This comment was supported by 36 more TEs who made their work schedules in advance to manage and save time, energy and stress and achieve organisational goals. This success led them to achieve JSM in their daily professional lives, and this, in turn, positively affected their personal and family lives. The TEs who were satisfied with their professional, personal and family lives also appeared to progress better than unsatisfied TEs.

\section{Discussion}

This article has attempted to shed light on the most common experiences of the 40 interviewed TEs by directly quoting a representative sample of 13 TEs. By using this representative sampling approach, we hope to reflect the functions and meanings communicated by all TEs during their interviews.

The data identified several TM activities that TEs use in their daily professional lives to achieve JSM. These TM activities included pre-planning, reviewing and updating outlines, offering counselling and guidance, designing material resources, ensuring a detailed distribution of marks, developing examination schedules, managing and discussing assessment and evaluation styles, discussing and addressing students' objections, publishing results, and making work schedules in advance. These practices are similar to those found among public and private school teachers, who have been shown to manage their time through wise planning, the careful design of activities, proper implementation, working hard to manage activities and time, priority-setting, regularity, punctuality, advance preparation for lectures and activities and the review and repetition of lectures (Sahito at el., 2016). These TM skills and characteristics can be integrated into TEs' daily routines through different training programs to support positive changes in TEs' attitudes and behaviours. It has been found that individuals actively and frequently engage in TM behaviours after attending a training program (Green \& Skinner, 2005; King et al., 1986; Macan, 1994; Slaven \& Totterdell, 1993; Van Eerde, 2003). Similarly, research has shown that that TM training is positively correlated with teachers' performance (Hall \& Hursch, 1982; King et al., 1986; Orpen, 1994).

The data also revealed that in some newly established institutions and universities, TEs face several TM hurdles, such as unnecessary meetings that do not convey any work- or assignment-related information. Such meetings often discuss other assignments, which can prevent goal achievement because university teachers' main responsibilities are teaching, training and research, in that order. Though TEs often engage in different activities, such as preparing students for competitions (either related to their expertise or not), department administrators often delegate these responsibilities based on preference, not expertise. Thus, though the TEs' workloads remain the same, they gain additional responsibilities and become too exhausted and overburdened to manage their responsibilities. Assignment overload can prevent teachers from practicing TM and cause dissatisfaction and demotivation. However, many teachers also feel blessed to be in a respectable and highly paid profession; thus, they feel positively about themselves, and this can increase their professional and personal satisfaction (Dodd \& Sundheim, 2005). To achieve 
maximum satisfaction, employees should plan all of their activities and assignments in advance. They should develop working schedules, review outlines, create related materials, write notes and make presentations by allocating time slots appropriately. This approach can help TEs implement their plans effectively. TEs should also discuss their plans with their department heads and submit their plans for approval. Furthermore, they should discuss their plans with their students during the first lecture class of each semester. As different activities are conducted in the classroom, TEs should announce upcoming and future activities; this allows students to plan for these activities' requirements and guidelines. In this way, both TEs and students can work to manage their time and activities to fulfil their responsibilities and support organisational quality. To support such continuing improvement, many of the TEs in this study recommended allowing students to come to their teachers or email them for help, discussion, counselling and guidance. The majority of TEs believed that helping and guiding students is their prime responsibility and that such activities can increase students' satisfaction and motivation. This satisfaction is directly and significantly correlated with TEs' progress and JSM. Thus, to achieve JSM, TEs should implement advance planning to effectively manage their time and activities and ensure that systems run smoothly.

The interviewed TEs identified ten factors and characteristics as critical for achieving JSM. First, TEs must spend time, meaning that they should engage in realistic planning and estimate the time required for all types of activities. Managing time effectively requires recognising importance and urgency (MacKenzie, 1990). The time management matrix divides activities into four quadrants: urgent, not urgent, important and not important (Covey, Merrill \& Merrill, 1994). Planning and using tools effectively is also critical. TEs can use the internet and calendars to retrieve different files and prepare themselves for class (Beckwith, 2006). Personal digital assistants (PDA) and notebooks can also be used to record everything (Morgenstern, 2004) and to keep track of activities. TEs should also organise activities using five steps: complete it, delegate it, act on it, file it temporarily and file it permanently (Dodd \& Sundheim, 2005). Furthermore, TEs should schedule assignments appropriately and always have a plan B. Between assignments, TEs should prepare activities for students to work on, such as writing letters, reading books or articles or listening to educational audiotapes (Lakein, 1973). Delegating time and work means getting help or involving someone else in the completion of assignments. For example, TEs can recruit competent students as team members to help them in their work. TEs should also stop procrastinating, meaning that they should not stop doing work just because they are in an unpleasant mood. To avoid procrastination, TEs can do work in stages to avoid stress and maintain interest, satisfaction and motivation. TEs can also minimise and manage external time wasters, such as telephone calls, chatting, email replies, unexpected visitors, meetings and other obligations. It is also important for TEs to focus on one task at a time and avoid multi-tasking, which wastes time and reduces productivity by forcing an individual to switch from one task to another (Rubinsteim, Meyer, \& Evans, 2001). Finally, when employees feel positive to reduce stress and stay healthy, they will work better and achieve higher satisfaction and motivation. Ultimately, the TEs who perceived their time as precious and prioritised their activities and assignments based on their importance for achieving organisational goals were found to have the highest levels of JSM.

\section{Conclusion}

Based on the collected data and findings, this study concludes that TEs who achieve JSM are those who know how to: spend their time, set priorities, plan, organise their activities, schedule their assignments, delegate their time and work, stop procrastinating, minimise and manage external time wasters, focus on one task at a time and avoid multi-tasking and feel positive to reduce stress and stay healthy. In many universities and institutions in Pakistan, teachers spend their time doing different non-productive and unrelated activities. Most of the time, TEs think about and resolve their problems using different types of propagandas and issues related to departmental administration and organisational management. TEs also face student-teacher-related problems, such as class implementation, practicums, attendance and the filling out of examination forms. In most cases, TEs do not address these issues through any kind of input, planning or implementation process; instead, they avoid the problems by diverting them towards junior TEs (i.e. lecturers). This approach protects TEs from the pressures of students, parents, the community, higher officials, politicians, pressure groups and top management; however, such practices are unethical and can damage TEs' overall TM planning and affect their JSM.

To address these issues, department heads and top management personnel in educational institutions and universities must understand the phenomena of TM and JSM in order to support TEs in planning different policies for maintaining security, respect and peace of mind within their institutions and in relation to all stakeholders. Advance planning, suitable policy-making and proper implementation support positive and effective results, which help all members of an institution think, act and work in a positive manner and prevent critical and negative people from interfering in the system. 


\section{References}

Adams, G. A., \& Jex, S. M. (1999). Relationships between time management, control, work-family conflict, and strain. Journal of Occupational Health Psychology, 4(1), 72-77. https://doi.org/10.1037/1076-8998.4.1.72

Ajzen, I. (1991). The theory of planned behavior. Organizational Behavior and Human Decision Processes, 50(2), 179-211. https://doi.org/10.1016/0749-5978(91)90020-T

Allen, D. (2001). Getting things done: the Art of Stress-Free Productivity. New York: Viking.

Alvani, C. M. (2008). Public management. Tehran: Ney publication.

Ancona, D. G., Goodman, P. S., Lawrence, B. S., \& Tushman, M. L. (2001). Time: a new research lens. Academy of Management Review, 26, 645-63. http://www.jstor.org/stable/3560246

Barling, J., Cheung, D., \& Kelloway, E. K. (1996). Time management and achievement striving interact to predict car sales performance. Journal of Applied Psychology, 81(6), 821-826. https://doi.org/10.1037/0021-9010.81.6.821

Beckwith, S. (2006, July). Unleash Your PDA's Power. Black Enterprise, 36(12), 66.

Bond, M., \& Feather, N. (1988). Some correlates of structure and purpose in the use of time. Journal of Personality and Social Psychology, 55, 321-329. https://doi.org/10.1037/0022-3514.55.2.321

Britton, B. K., \& Tesser, A. (1991). Effects of time-management practices on college grades. Journal of Educational Psychology, 83, 405-410. https://doi.org/10.1037/0022-0663.83.3.405

Burt, C. D. B., \& Kemp, S. (1994). Construction of activity duration and time management potential. Applied Cognitive Psychology, 8, 155-68. https://doi.org/10.1002/acp.2350080206

Carroll, S. M. (2009). From Eternity to Here: The Quest for the Ultimate Theory of Time. New York: Dutton, an imprint of Penguin random house LLC.

Claessens, B. J. C., Eerde, W. V., Rutte, C. G., \& Roe, R. A. (2007). A review of the time management literature. Personnel Review, Emerald Group Publishing Limited, 36(2), 255-276. https://doi.org/10.1108/00483480710726136

Claessens, B. J. C., Van Eerde, W., Rutte, C. G., \& Roe, R. A. (2004). Planning behavior and perceived control of time at work. Journal of Organizational Behavior, 25(8), 937-950. https://doi.org/10.1002/job.292

Clandinin, D. J., \& Connelly, F. M. (2000). Narrative Inquiry: Experience and story in qualitative research. Published by Jossey-Boss, John Wiley \& Sons, Inc., San Francisco.

Covey, S. R., Merrill, A. R., \& Merrill, R. R. (1994). First Things First: To Live, to Love, to Learn, to Leave a Legacy. New York: Simon \& Schuster.

Creswell, J. W. (2012). Educational research: planning, conducting, and evaluating quantitative and qualitative research, $4^{\text {th }}$ (ed.). Pearson Education, Inc., Boston, USA.

Creswell, J. W. (2009). Research design: Qualitative, quantitative and mixed methods approaches, $3^{\text {rd }}$ (ed.). London, England: Sage Publications.

Crotty, M. (1998). The foundations of social research: Meaning and perspective in the research process. London, England: Sage Publications.

Davis, M. A. (2000). Time and the nursing home assistant: relations among time management, perceived control overtime, and work-related outcomes, paper presented at the Academy of Management, Toronto.

David A. S. (1999). The Concise Dictionary of Business Management, London: Taylor \& Francis Group.

Dodd, P., \& Sundheim, D. (2005). The 25 Best Time Management Tools and Techniques: How to Get More Done Without Driving Yourself Crazy. Ann Arbor, MI: Peak Performance Press, Inc.

Douglas, B. (2006). Metaphysics - 7, Space, Time, and Indiscernibles. Staffordshire University, Gottfried Wilhelm Leibniz (1646-1716). Retrieved on 3 March, 2017 from http://www.iep.utm.edu/leib-met/\#H7

Eilam, B., \& Aharon, I. (2003). Students planning in the process of self-regulated learning. Contemporary Educational Psychology, 28, 304-334. http://dx.doi.org/10.1016/S0361- 476X (02)00042-5

Etherington, K. (2000). Narrative approaches to working with adult male survivors of childhood sexual abuse. London: Jessica Kingsley. 
Etherington, K. (2006). Chicken or egg? An exploration of the relationships between physical and psychological symptoms with a woman diagnosed with Tourette's syndrome. In Counselling and Psychotherapy Research, 6(2), 138-146. https://doi.org/10.1080/14733140600711500

Etherington, K. (2007). Ethical research in reflexive relationships. Qualitative Inquiry, 13(50), 599-616. https://doi.org/10.1177/1077800407301175

Flick, U. (1998). An introduction to qualitative research. London, England: Sage Publications.

Francis-Smythe, J.A., \& Robertson, I.T. (1999). On the relationship between time management and time estimation. British Journal of Psychology, 90, 333-47. https://doi.org/10.1348/000712699161459

Frank, A. (2011). Cosmology and Culture at the Twilight of the Big Bang. New York: Simon \& Schuster, Free Press.

Garhammer, M. (2002). Pace of Life and Enjoyment of Life. Journal of Happiness Studies, 3, 217-256. http://dx.doi.org/10.1023/A: 1020676100938

George, J. M. \& Jones, G.R. (2000). The role of time in theory and theory building. Journal of Management, 26(4), 657-684. https://doi.org/10.1177/014920630002600404

Goldring, E., Huff, J., May, H., \& Camburn, E. (2008). School context and individual characteristics: What influences principal practice? Journal of Educational Administration, 46(3), 332-352. https://doi.org/10.1108/09578230810869275

Green, P., \& Skinner, D. (2005). Does time management-training work: an evaluation. International Journal of Training and Development, 9, 124-39. http://dx.doi.org/10.1111/j.1468-2419.2005.00226.x

Griffiths, R. F. (2003). Time management in telework and other autonomous work environments, Dissertation Abstract International: Section B: The Sciences and Engineering, 64, p. 5B.

Grissom, J. A., Loeb, S. \& Master, B. (2013). Effective Instructional Time Use for School Leaders: Longitudinal Evidence from Observations of Principals. Educational Researcher, 42(8), 433-444. https://doi.org/10.3102/0013189X13510020

Hall, B. L., \& Hursch, D. E. (1982). An evaluation of the effects of a time management-training program on work efficacy. Journal of Organizational Behaviour Management, 3, 73-98. https://doi.org/10.1300/J075v03n04_08

Hallinger, P. \& Heck, R. H. (1998). Exploring the Principal's Contribution to School Effectiveness: 1980-1995. School Effectiveness \& School Improvement, 9(2), 157-191. https://doi.org/10.1080/0924345980090203

Hallinger, P. \& Murphy, J. F. (2013). Running on Empty? Finding the Time and Capacity to Lead Learning. NASSP Bulletin, 97(1), 5-21. https://doi.org/10.1177/0192636512469288

Horng, E. L., Klasik, D., \& Loeb, S. (2010). Principal's time use and school effectiveness. American Journal of Education, 116(4), 491-523. https://doi.org/10.1086/653625

Institute for Educational Leadership. (2000). Leadership for Student Learning: Reinventing the Principalship, Institute for Educational Leadership. Washington, DC.

Jackson, P. R., \& Martin, R. (1996). Impact of just in time on job content, employee attitudes and well-being: a longitudinal study. Ergonomics, 39(1), 1-16. https://doi.org/10.1080/00140139608964429

Jamal, M. (1984). Job stress and job performance controversy: An empirical assessment. Organizational Behavior and Human Performance, 33(1), 1-21. https://doi.org/10.1016/0030-5073(84)90009-6

Javaheri, Z. N. (2005). Studying time management skills and features in Tehran city guidance schools comparing with desired condition. Two-month research quarterly, 12.

Jex, J. M., \& Elacqua, T. C. (1999). Time management as a moderator of relations between stressors and employee strain. Work \& Stress, 13, 182-91. https://doi.org/10.1080/026783799296138

Judge, T. A., Thoreson, C. J., Bono, J. E., \& Patton, G. K. (2001). The job satisfaction and job performance relationship: A qualitative and quantitative review. Psychological Bulletin, 127(3), 376-407. https://doi.org/10.1037/0033-2909.127.3.376

Kaufman-Scarborough, C., \& Lindquist, J. D. (1999). Time management and polychronicity: comparisons, contrasts, and insights for the workplace. Journal of Managerial Psychology, 14, 288-312. https://doi.org/10.1108/02683949910263819

Khodaveisi, M., Bahar, G. S., \& Ahmadi, S. (2015). The Relation between time management and job stress in physical education lecturers and faculty members of Hamedan Universities. Sport Science, 8(1), 60-63. 
King, A. C., Winett, R. A., \& Lovett, S. B. (1986). Enhancing coping behaviours in at-risk populations: the effects of time-management instruction and social support in women from dual-earner families. Behaviour Therapy, 17 , 57-66. https://doi.org/10.1016/S0005-7894(86)80114-9

Lakein, A. (1973). How to Get Control of your Time and Life. Nal Penguin Inc., New York, NY.

Lay, C. H., \& Schouwenburg, H. C. (1993). Trait procrastination, time management, and academic behavior. Journal of Social Behavior and Personality, 8, 647-662.

Macan, T. H. (1996). Time-management training: effects on time behaviours, attitudes, and job performance. The Journal of Psychology, 130, 229-36. https://doi.org/10.1080/00223980.1996.9915004

Macan, T. H. (1994). Time management: test of a process model. Journal of Applied Psychology, 79, 381-391. https://doi.org/10.1037/0021-9010.79.3.381

Macan, T. H., Shahani, C., Dipboye, R. L., \& Philips, A. P. (1990). College students' time management: correlations with academic performance and stress. Journal of Educational Psychology, 82, 760-768. https://doi.org/10.1037//0022-0663.82.4.760

MacKenzie, A. (1990). The Time Trap $3^{\text {rd }}$ (ed.). New York: American Management Association.

Major, V. S., Klein, K. J., \& Ehrhart, M. G. (2002). Work time, work interference with family, and psychological distress. Journal of Applied Psychology, 87, 427-36. https://doi.org/10.1037//0021-9010.87.3.427

Mancini, M. (2003). Time Management. New York: McGraw-Hill. DOI: 10.1036/0071425578.

Mattey, G. J., \& Davis, U. C. (1997). Critique of Pure Reason, Lecture notes: Philosophy 175 UC Davis. Retrieved 3 March 2017. http://www-philosophy.ucdavis.edu:80/mattey/kant/TIMELEC.HTM

https://web.archive.org/web/20050314201600/

Matt, M. (2006). Metaphysics: 4. Kant's Transcendental Idealism. California State University, Immanuel Kant (1724-1804). The Internet Encyclopedia of Philosophy. Retrieved 3 March 2017. http://www.iep.utm.edu/time/

May, H., Huff, J., \& Goldring, E. (2012). A longitudinal study of principals' activities and student performance. School Effectiveness and School Improvement, 23(4), 417-439. ERIC Number: EJ984230. https://doi.org/10.1080/09243453.2012.678866

Mohammadi, G. M. J. (2010). Time management and its components among Islamic Azad University students. Social Research Quarterly, 2(6), 57-73.

Moghimi, C. M. (2006). Organization and Management: Research approach. Tehran: Terme publication.

Morgenstern, J. (2004). Time Management from the Inside Out. New York: Henry Holt and Company.

Mudrack, P. (1997). The structure of perceptions of time. Educational and Psychological Measurement, 57, 222-240. https://doi.org/10.1177/0013164497057002003

Orpen, C. (1994). The effect of time-management training on employee attitudes and behaviour: a field experiment. The Journal of Psychology, 128, 393-396. https://doi.org/10.1080/00223980.1994.9712743

Palmer, D. K., \& Schoorman, F. (1999). Unpackaging the multiple aspects of time in polychronicity. Journal of Managerial Psychology, 14(3-4), 323-344. https://doi.org/10.1108/02683949910263918

Peeters, M. A. G., \& Rutte, C. G. (2005). Time management behavior as a moderator for the Job demand-control interaction. Journal of Occupational Health Psychology, 10(1), 64-75. https://doi.org/10.1037/1076-8998.10.1.64

Polkinghorne, D. E. (1995). Narrative configuration in qualitative analysis. Qualitative studies in education, 8(2), 5-23. https://doi.org/10.1080/0951839950080103

Radhakrishna, R. B., Yoder, E. P., \& Baggett, C. (1991). Time management and performance. Journal of Extension, 29(2), 33-34.

Riessman, C. K. (2008). Narrative methods for the human sciences. London: Sage.

Robinson, V. M. J., Lloyd, C. A., \& Rowe, K. J. (2008). The impact of leadership on school outcomes: An analysis of the differential effects of leadership types. Educational Administration Quarterly, 44(5), 635-674. https://doi.org/10.1177/0013161X08321509

Rubinsteim, J., Meyer, D. \& Evans, J. (2001). Executive control of cognitive processes in task switching. Journal of Experimental Psychology Human Perception and Performance, 27(4), 763-797. https://doi.org/10.1037//0096-1523.27.4.763 
Sabelis, I. (2001). Time management: paradoxes and patterns. Time \& Society, 10, 387-400. http://tas.sagepub.com/content/10/2-3/387.

Sahito, Z., Khawaja, M., Panhwar, U. M, Siddiqui, A., \& Saeed, H. (2016). Teachers' time management and the performance of students: A Comparison of government and private schools of Hyderabad, Sindh, Pakistan. World Journal of Education, 6(6), 42-50. https://doi.org/10.5430/wje.v6n6p42

Schuler, R. S. (1979). Managing stress means managing time. Personnel Journal, 58(12), 851-854.

Shaw, I., \& Gould, N. (2001). Qualitative research in social work. London, England: Sage Publications. https://doi.org/10.4135/9781849209694

Slaven, G., \& Totterdell, P. (1993). Time management training: does it transfer to the workplace? Journal of Managerial Psychology, 8, 20-28. https://doi.org/10.1108/02683949310024432

Sparkes, A. C., \& Smith, B. (2014). Qualitative research methods in sport, exercise and health from process to product. Oxford, England: Routledge. https://doi.org/10.1080/2159676X.2013.796493

Sparkes, A. C., \& Smith, B. (2009). Judging the quality of qualitative inquiry: Criteriology and relativism in action. Psychology of Sport and Exercise, 10, 491-497. https://doi.org/10.1016/j.psychsport.2009.02.006

Spillane, J. P., Camburn, E. M., \& Pareja, A. S. (2007). Taking a distributed perspective to the school principal's workday. Leadership and Policy in Schools, 6(1), 103-125. https://doi.org/10.1080/15700760601091200

Spillane, J. P., \& Hunt, B. R. (2010). Days of their lives: A mixed-methods, descriptive analysis of the men and women at work in the principal's office. Journal of Curriculum Studies, 42(3), 293-331. https://doi.org/10.1080/00220270903527623

Strauss, A., \& Corbin, J. (1998). Basics of qualitative research: Techniques and procedures for developing grounded theory, $2^{\text {nd }}$ (ed.). Thousand Oaks, CA: Sage.

Strongman, K. T., \& Burt, C. D. B. (2000). Taking breaks from work: an exploratory inquiry. Journal of Psychology, 13(4), 229-242. https://doi.org/10.1080/00223980009600864

Teuchmann, K., Totterdell, P., \& Parker, S. K. (1999). Rushed, unhappy, and drained: an experience sampling study of relations between time pressure, perceived control, mood, and emotional exhaustion in a group of accountants. Journal of Occupational Health Psychology, 4(1), 37-54. http://dx.doi.org/10.1037/1076-8998.4.1.37

Time. (2011). The Concise Oxford Dictionary, $12^{\text {th }}$ (ed.). Oxford University Press Inc., New York. https://en.oxforddictionaries.com/definition/time

Time. (2010). Internet Encyclopedia of Philosophy. http://www.iep.utm.edu/time/

Time. (2010). Webster's New World College Dictionary, $4^{\text {th }}$ (ed.). IDG Books Worldwide, Inc. An International Data Group Company, Foster City, CA. http://www.yourdictionary.com/time

Time. (2011). The American Heritage Dictionary of the English Language $4^{\text {th }}$ (ed.). Houghton Mifflin Company, Boston. https://ahdictionary.com/word/search.html?q=time

Time. (2001). The New Oxford Dictionary of English. Oxford University Press Inc., UK. https://en.wikipedia.org/wiki/Oxford_Dictionary_of_English

Tracy, S. J. (2010). Qualitative quality: Eight big-tent, criteria for excellent qualitative research. Qualitative Inquiry, 16(10), 837-851. https://doi.org/10.1177/1077800410383121

Van Eerde, W. (2003). Procrastination at work and time management training. Journal of Psychology, 137, 421-434. https://doi.org/10.1080/00223980309600625

Vodanovich, S.J., \& Seib, H.M. (1997). Relationship between time structure and procrastination. Psychological Reports, 80, 211-215. https://doi.org/10.2466/pr0.1997.80.1.211

Wosket, V. (1999). Therapeutic use of self: Counselling practice, research and supervision. London: Routledge. https://doi.org/10.4324/9780203448670

Woolfolk, A. E., \& Woolfolk, R. L. (1986). Time management: an experimental investigation. Journal of School Psychology, 24, 267-75. http://dx.doi.org/10.1016/0022- 4405(86)90059-2

Wright, T. A. (2002). Dialogue: the importance of time in organizational research. Academy of Management Journal, 45, 343-5. 